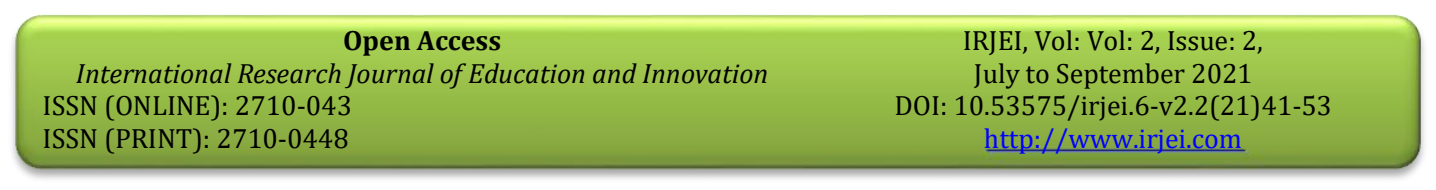

Effect of Experiential Learning on Students' Motivation and Interest at Elementary Level

July-Sep 2021

Effect of Experiential Learning on Students' Motivation and Interest at Elementary Level in the Subject of General Science

Bibi Rukhsana*

Dr. Muhammad Naeemullah**

Dr. Sajid Rehman ${ }^{* * *}$

\begin{abstract}
The research was conducted to explore the effect of experiential learning on students' motivation and interest at elementary levels in the subject of General Science. The purposes of research were, (i) to measure the influence of experiential studying on student's motivation towards learning, (ii) to examine the influence of experiential learning on student's interest toward learning. The null hypothesis were designed to test the objectives as (i) there was no meaningful difference among the motivation of experimental groups and control groups, (ii) no significant difference was there between the mean scores of experimental group and control group on post-test. The $5^{\text {th }}$ class students of WAPDA Senior Model School Tarbela Dam Project was taken randomly as example of research. The research was experimental in nature. The pretest, posttest Equivalent Group Designs was used. Both experimental and control groups had equated upon the footing of researcher made pre-test scores. Both groups were exposed to same course but their style of learning was different. Experiential learning method was selected for experimental group for the period of six weeks duration. Researcher made pretest, posttest and observations sheets used as data collection tools. The data was investigated by employing mean score and t-test. Results indicate that the students of experimental group was more motivated resultantly they performed significantly better than control groups upon posttest presenting the supremacy of the experiential learning upon old-style learning. It was found through observation sheet that experiential learning developed strong motivation and interest in experimental group students. It was concluded that experiential learning was effective in teaching science at elementary grade. It was recommended that the teachers should be trained to teach students by experiential learning. The training institution should train the teachers to use different methods of teaching such as experiential learning. In this way all the students' motivation and interest will increase. Resultantly students' academic performance will also increase.
\end{abstract}

Keywords: Experiential learning, student's motivation/Interest, Elementary level, General science.

\title{
Introduction
}

Humans and animals both have the ability to learn. Humans learn through frequent interactions with other people and the environment after birth and throughout their lives. Different types of learning theories describe how humans acquire, process, and retain information to explain how they learn. Each person has their unique learning method. Visual, aural, and discovery learning strategies are all prominent. Visual learners learn quickly by doing activities like observing, reading, creating diagrams, and looking at pictures. Listening, reading, teaching, discussing, and hearing are all activities that auditory learners engage in. Active learners who participate in the activities such as experiencing and learning are known as kinesthetic learners. The motivation and interest of students play a critical role in

${ }^{*}$ PhD scholar Northern University Nowshehra.

${ }^{* *}$ Associate professor, Northern University Nowshehra.

Email: naeemullah@northern.edu.pk

${ }^{* * *}$ Assistant Professor, Northern University Nowshehra.

= International Research Journal of Education and Innovation 
improving their academic performance. The experiential learning approach of instruction promotes the teacher in increasing student interest and motivation. It will have a long-term effect. It requires developing information through practice or learning. In 1970s, Kolb established the most contemporary theory of the experimental learning, based upon work of Dewy, Kurt Lewin, and Jean Piaget. Experimental learning has replaced traditional method of the learning, in which only students were passive and a behavioural approach was employed to teach certain actions to them. (Kamath, 2014; Javed, Hussain, \& Karim, 2014; Jeyaraj, 2019). With a constructivist approach, learning is now cognitive and social, and students participating in active learning support the idea of meaningful learning. Experiential learning occurs when students apply what they've learned in class to real-life events in order to increase their comprehension and learning (Chana, 2012).

Students benefit more from hands-on learning than from lectures. In a real-world situation, experiential learning helps students to combine their awareness of global concerns with the implementation of effective pro-social action techniques. Studying abroad is one type of experiential learning platform that has grown to be recognized as a great way to learn about different cultures while also generating transformative cultural awareness and experiences. (Earnest et al., 2015; Reade et al., 2013; Strange \& Gibson, 2017).

Experiential learning is based on a well-structured learning cycle with specified learning objectives. They encourage students to actively create knowledge and critically reflect on their experiences, allowing them to realise how their skills and knowledge can be applied to future undertakings. Students have been shown to benefit from studying abroad in a variety of ways. It encourages students' personal and moral development, as well as their multicultural skills, global awareness, and feeling of responsibility. (K.R. Stoner et al., 2014; Tiessen \& Epprecht, 2012); provide powerful chances for the analytical selfreflection, examination, and combination (L. Stoner et al., 2014).

Pupils gain information at the expense of involvement in traditional instruction, which is mainly theory-based (Chmielewski-Raimondo et al., 2016; Kolb \& Kolb, 2005). Experimental Learning Theories, upon other hand, encourages self-improvement through continuous skill and knowledge reformation. Students gain information at the expense of involvement in traditional instruction, which is mainly theory-based (Chmielewski-Raimondo et al., 2016; Kolb \& Kolb, 2005). Experimental Learning Theories, upon other hand, encourages selfimprovement through continuous skill and knowledge reformation. (Bonnycastle \& Bonnycastle, 2010; Lewis et al., 2017; Lin et al., 2016).

\section{Motivation and Interest}

According to Kolb and Kolb (2005), experiential learning is a repeated pattern in which students participate in an event, reflect on that experience, and develop new ideas that are subsequently implemented (Henoch et al., 2014; Lewis et al., 2017). The significance of motivation in a student's educational life cannot be emphasized. Motivation has gained the greatest attention in research due to its importance. Researchers, on the other hand, frequently examine the cognitive aspects of motivation in relation to academic 
accomplishment. According to Zhu and Yang (2012), motivation is a psychological proclivity and internal urge that stimulates and regulates an organism's activity. Effective motivation factors such as fundamental and extrinsic stimulus were not valued highly through researchers. The students' desire to enhance their performance is ignored, especially in the context of Pakistan. The conclusions of research accompanied in the other republics were not relevant or appropriate in Pakistan country due to social differences. A lot of psychologists have developed motivation theories. There are two types of theories: content theory and process theory. Content theory were concerned with reflexes which drive public toward labour (Turabik \& Baskan, 2015). These philosophies undertake that everyone has same needs, and that these needs motivate people to act or fulfil them. Such theories contain Maslow's hierarchy of the needs, Herzberg's Two-factor theories, McClelland's desire for the performance theories and Alfred's E.R.G theories. Processed theories emphasise individual variability in cognition. Students who are highly motivated perform well, and their performance has remained dominating.

\section{Related Researches}

Experiential learning promotes students to become critical thinkers and problem solvers in a variety of professions, including psychology, business, social work, and nursing (Chavan, 2011; Greenfield et al., 2012; Roholt \& Fisher, 2013). Nurses who participated in specialised political experiential learning activities became more encouraged to engage in purposeful advocacy in the healthcare field, according to McGuire et al., (2017). De Groot et al. (2015) looked into the learning outcomes of kinesiology students who participated in experiential learning. These lectures encouraged students in getting real-world experience, increasing independence, and moving attitudes toward better empathy and understanding, according to the research.

Teaching and learning do not have to take place solely in the classroom, as is typically the case in traditional education, according to studies. According to Lin et al., students in Northern Taiwan improved their self-actualization, communication skills, and relationships as a result of their participation in experiential learning activities on and off campus (2016). Chen (2012) claims that university students who participated in local community earthquake rebuilding operations were driven to contribute for the sake of cultural identity. Furthermore, both previous studies revealed that students' experiences resulted in new goals for positive societal change. Philips et al. (2017) studied students who participated in a study abroad programme in Ghana. According to their research, the students' pre-trip assumptions of Ghanaians were incorrect and biased, but after the trip, they had a higher appreciation for the local culture and a better understanding of the population's social difficulties.

Experimental science instruction can be taken place in variety of the locations, including gardens, galleries, public library, menageries, and the other places from where kids may learn while doing fun (Yoon, Elinich, Wang, , \& Anderson, 2013, Van Schooneveld ,Holmes, 2011. In addition, intended involvements that permit youngsters to choose actions give them voice, and allow them to create decisions which are related and important to life of them, so combining cultural significance. 
Various people have defined the term "motivation" in a variety of ways. It is, at its most fundamental level, a call to action. Motivation is the term used to describe the reasons for engaging in a particular activity (Lai, 2011). Motivation, in its most basic form, is the force that allows people to channel and empower their energy and passion in order to achieve higher levels of satisfaction and educational performance (Coetzee, 2011).

\section{The Statement of Problem}

The purposes of investigation were to see how experiential learning affected students' motivation and interest in general science at the basic level. Curriculum developers, researchers, teachers, and students will benefit from this research in the future.

\section{Objectives}

- To measure the effect of experimental learning upon pupil's motivation towards learnings.

- To examine the impact of experimental learning on pupils interest toward learning.

\section{Method and procedure Population}

The population contained the 5th-grade pupils studying General Science at the elementary level.

\section{Sample}

One school, WAPDA Senior Model School Tarbela Dam Project, was chosen for the research study utilizing convenient sampling technique. This study had a total of 40 female students.

\section{Research Design}

The research was experimental. The students were separated in 2 groups: experimental group and control group. According to Farooq and Tabassum (2017) the pretest and posttest equivalent group designs were applied to measure effectiveness of the treatment that involved two equivalent groups the mentioned below was symbolic demonstration of the research designs.

Where

\begin{tabular}{|ll|}
$\mathrm{R}_{\mathrm{E}}=\mathrm{O}_{1} \quad \mathrm{~T}$ & $\mathrm{O}_{2}$ \\
$\mathrm{R}_{\mathrm{C}}=\mathrm{O}_{3}$ & $\mathrm{O}_{4}$ \\
\hline $\mathrm{dR} \mathrm{R}_{\mathrm{E}}=\mathrm{O}_{2}-\mathrm{O}_{1}$ \\
$\mathrm{dR_{ \textrm {C } }}=\mathrm{O}_{4}-\mathrm{O}_{3}$ \\
\hline $\mathrm{D}=\mathrm{dR_{ \textrm {E } } -}-\mathrm{dR} \mathrm{R}_{\mathrm{C}}$ \\
\hline
\end{tabular}


$\mathrm{R}_{\mathrm{E}}=$ Selected the Experimental Group Randomly

$\mathrm{R}_{\mathrm{C}}=$ Selected The Control Group Randomly

$\mathrm{O}_{1}$ and $\mathrm{O}_{3}=$ observation of the pre-test

$\mathrm{O}_{2}$ and $\mathrm{O}_{4}=$ observation of the posttests

$\mathrm{T}=$ Treatment (teaching by experiential learning model)

$\mathrm{d}=$ variance between the mean scores of the pretest, and posttest.

\section{Research Instrument}

Data were collected by mentioned tools.

\section{Pretest and Posttest}

Investigator developed pretest and posttest. Both were developed on the basis of the cognitive domain, including lesson plan objectives as well as study objectives.

\section{Observation Sheet}

Observation sheets were prepared to explore the interest and motivation. Every student's cognitive, emotional, and psychomotor domains were assessed. Each observation sheet contained 36 items.

\section{Treatment}

The treatment of this research study was given to

Experimental group and the control group, two teachers with similar experience and qualifications were chosen. For the instruction, four lessons from the General Science 5th grade book were selected. The following are the lessons:-

(i) Seed Structure and Germination,

(ii) Environmental Pollution,

(iii) Matter and Changes in its states,

(iv) Forces and Machines.

These teachings were delivered to the two groups over a six-week period. The experiential learning concept was used to create lesson plans. During the treatment, the researcher and assistant observed the experimental group. The usual lecture demo technique was applied to treat the control groups. Same course content taught to both groups. After the six-week instructional period was completed, all sample students were given a post-test.

\section{Procedure}

The researcher for the research study subjects developed two sets of lesson plans. Each set of lesson plans included six weeks' worth of subjects. Each class lasted forty minutes in duration. Rising out of learning experiences were specific objectives and hands-on practices. One set of lesson plans was planned for the experimental group that was based on experiential learning. In all of their activities, the teacher and the students followed the experiential learning. The activities of the students were carried out with the help of the teacher. The teacher was in fact encouraging instructional methods and practices that compel pupils to engage in experiential learning. The experimental group's teacher used this teaching method at various points of the instructional process, as shown in the lesson plan. 
On the other hand the $2^{\text {nd }}$ set of lessons plan was prepared for traditional lecture demonstration method of teaching.

\section{Data Collection}

Pre-test was given to the study's sample student in order to divide them into two equal groups based on their pre-test scores. Lessons were taught to the experimental group through experiential learning, whereas the control groups were taught using the old-style (lecture demonstration) technique. Treatment continued for six weeks. Post-test was given after the six-week treatment to assess the efficiency of the treatment. The data was collected by instructors (research assistants) using a questionnaire with options A to D that was delivered to the sample pupils in a set amount of time. Each student's scores were grouped according to their level of achievement.

Observation sheets constituting the indicators of interest and motivation were observed by the researcher.

\section{Analysis of Data}

Percentages, means, median, standard deviations, and T-test applied to examine data. The mean scores were applied to determine overall presentation of both groups, and T-test was applied to define whether a significant difference was accrued in pretest and posttest marks between experimental group and control group.

\section{Consequences and Discussion}

Pre-test Scores

Table 1:The Frequency distribution of the pretest score of the experimental and the control group

\begin{tabular}{ccc} 
Class Interval & $\begin{array}{c}\text { Frequencies of the } \\
\text { Experimental groups }\end{array}$ & $\begin{array}{c}\text { Frequencies of the } \\
\text { Control groups. }\end{array}$ \\
\hline $3-5$ & 4 & 2 \\
$6-8$ & 4 & 6 \\
$9-11$ & 6 & 6 \\
$12-14$ & 5 & 4 \\
$15-17$ & 1 & 2 \\
$18-20$ & 0 & 0 \\
$21-23$ & 0 & 0 \\
$24-26$ & 0 & 0 \\
Total & $\mathbf{2 0}$ & $\mathbf{2 0}$ \\
Mean & $\mathbf{9 . 1 0}$ & $\mathbf{9 . 5 0}$ \\
\hline
\end{tabular}

The mean value of both the groups were almost equal that is shown in above table 1 and 
frequencies were normally distributed. The ranges of the pre-test scores were from 3 to 26 of experimental and control groups which shows equivalent before treatment.

Table 2. t-test results and difference in mean score of the pretest among the experimental group and the control group

\begin{tabular}{lccccc}
\hline Groups & $\mathbf{N}$ & Mean & SD & SE $_{\mathbf{D}}$ & t value \\
\hline Experimental & 20 & 9.10 & 3.417 & \multirow{2}{*}{1.081} & 0.370 \\
Control & 20 & 9.50 & 3.426 & & \\
df $=38$ & & \multicolumn{4}{c}{ the Table value at 0.05 level $=2.042$}
\end{tabular}

Table 02 shows that statistically no substantial variance was there among pre-test scores of the both groups of students' achievement in general science. The critical value $(0.370)$ was fewer than table value at 0.05 levels which supported null hypothesis. On basis of the pretest results, mean and SD shows that experimental group and the control group were alike before the treatment.

Ho: no significant difference was there among the mean scores of the experimental group and the control group using experiential learning.

\section{PostTest Scores}

Table 03: Frequency distribution of the post-test score of the experimental group and the control group..

\begin{tabular}{ccc}
\hline Class Intervals & $\begin{array}{c}\text { Frequencies of } \\
\text { Experimental group }\end{array}$ & $\begin{array}{c}\text { Frequencies of } \\
\text { Control group }\end{array}$ \\
\hline $3--5$ & 0 & 3 \\
$6--8$ & 2 & 2 \\
$9--11$ & 4 & 4 \\
$12--14$ & 2 & 2 \\
$15--17$ & 1 & 5 \\
$18--20$ & 4 & 3 \\
$21--23$ & 3 & 0 \\
$24--26$ & 4 & 1 \\
Total & $\mathbf{2 0}$ & $\mathbf{2 0}$ \\
Mean & $\mathbf{1 6 . 8 5}$ & $\mathbf{1 2 . 5 0}$ \\
\hline
\end{tabular}

Table 3 displays the frequency divisions of the posttest scores which mean the value of the experimental group was greater than mean value of the control groups. The ranges of the post-test scores started from 3 to 26 of experimental and control groups which showed mean difference among both the groups. The mean values of experimental group was 16.85 while mean values of control group was 12.50. That shows presentation of experimental group in posttest was much better than control group. 
Ho1: There is no significant difference between the mean score of experimental and control groups using experiential learning

Table 4. t-test results and difference in the means score of posttest score of the experimental group and the control group

\begin{tabular}{lcclcc}
\hline Groups & $\mathbf{N}$ & Mean & SD & SE $_{\mathbf{D}}$ & t value \\
\hline Experimental & 20 & 16.85 & 6.277 & \multirow{2}{*}{1.852} & \multirow{2}{*}{2.349} \\
Control & 20 & 12.50 & 5.405 & & \\
$\mathrm{df}=38$ & & \multicolumn{4}{c}{ The Table value at 0.05 level $=2.042$}
\end{tabular}

Table 4 indicates, statistically significant variance among the posttest score of the experimental group and the control group of the students' achievement in general science and investigated t-value (2.349) found bigger than table value at the 0.05 levels which excluded null hypothesis. On the basis of post-test results, mean and SD showed significant difference between the experimental group and the control group. Table value presents that experiential learning is significantly better than traditional learning.

\section{Analysis of Observation Sheets}

To measure the motivation and interest of sampled students the following observation sheets were observed and analyzed.

Table 5. Percentage of cognitive domain of students' achievement

\begin{tabular}{|c|c|c|c|c|}
\hline Sno & Statement & $\mathbf{N}$ & Yes & No \\
\hline 1 & Is the student attentive in class? & 20 & $20(100 \%)$ & $0(0 \%)$ \\
\hline 2 & $\begin{array}{l}\text { The student clearly communicates with } \\
\text { teacher and students? }\end{array}$ & 20 & $17 \quad(85 \%)$ & $3(15 \%)$ \\
\hline 3 & Is there freedom of learning to student? & 20 & $20(100 \%)$ & $0(0 \%)$ \\
\hline 4 & $\begin{array}{l}\text { Has the learner ability to recall } \\
\text { information? }\end{array}$ & 20 & $14(70 \%)$ & $6(30 \%)$ \\
\hline 5 & Can label the diagram correctly? & 20 & $(95 \%)$ & $1(5 \%)$ \\
\hline 6 & $\begin{array}{l}\text { Apply relates to situations in class } \\
\text { activities? }\end{array}$ & 20 & $(90 \%)$ & $2(10 \%)$ \\
\hline 7 & Can student understanding the topics? & 20 & $(100 \%)$ & $0(0 \%)$ \\
\hline
\end{tabular}

Table 5 shows under the cognitive domain of students achievement on the basis of experiential learning that $100 \%$ students were attentive in the class and understanding the topic and there were freedom of learning; $95 \%$ students labeled the diagram correctly, 90\% students applied relates to situation in class activities; $85 \%$ students clearly communicated 
with teacher, $70 \%$ students had learning ability to recall information.

Overall the percentage of cognitive domain ranged from $70 \%$ to $100 \%$. In cognitive domain the learning ability to recall information was $70 \%$ the lowest in the range. This showed highest level of motivation in cognitive domain.

Table 6. Percentage of affective domain of students' achievement

\begin{tabular}{|c|c|c|c|c|c|}
\hline Sno & Statement & $\mathbf{N}$ & & Yes & No \\
\hline 1 & Show interest in the class? & 20 & 20 & $(100 \%)$ & $0 \quad(0 \%)$ \\
\hline 2 & $\begin{array}{l}\text { The student actively participates in the class } \\
\text { during experiential learning process. }\end{array}$ & 20 & 20 & $(100 \%)$ & $0(0 \%)$ \\
\hline 3 & Feel enjoy helping other students? & 20 & 18 & $(90 \%)$ & $2(10 \%)$ \\
\hline 4 & Discuss with other students properly? & 20 & 15 & $(75 \%)$ & $5(35 \%)$ \\
\hline 5 & $\begin{array}{l}\text { Show responsibility for the functioning of her } \\
\text { group? }\end{array}$ & 20 & 15 & $(75 \%)$ & $5(25 \%)$ \\
\hline 6 & Participates as motivator? & 20 & 16 & $(80 \%)$ & $4(20 \%)$ \\
\hline
\end{tabular}

Table 6 indicates under the affective domain of students achievement on the basis of experiential learning that $100 \%$ students showed interest in the class and actively participated in the lesson; $90 \%$ students felt enjoy helping other students, $75 \%$ students showed responsibility for the functioning of her group; $75 \%$ students discussed with other students properly, $80 \%$ students participated as motivator while $35 \%$ students did not discuss with other students properly and $80 \%$ students participated as motivator.

The affective domain of students' achievement ranged from $75 \%$ to $100 \%$.

Table 7. Percentage of psychomotor domain of students' achievement

\begin{tabular}{|c|c|c|c|c|c|}
\hline Sno & Statement & $\mathbf{N}$ & & Yes & No \\
\hline 1 & $\begin{array}{l}\text { Being able to perform certain actions by } \\
\text { given instructions? }\end{array}$ & 20 & 20 & $(100 \%)$ & $0(0 \%)$ \\
\hline 2 & Respond effectively to experiences? & 20 & 17 & $(85 \%)$ & $3(25 \%)$ \\
\hline 3 & Observe and replicate in activities? & 20 & 15 & $(75 \%)$ & $5(25 \%)$ \\
\hline 4 & Felt any competent in tasks? & 20 & 17 & $(85 \%)$ & $3(15 \%)$ \\
\hline 5 & Concentrate on topic/activities? & 20 & 20 & $(100 \%)$ & $0(0 \%)$ \\
\hline 6 & $\begin{array}{l}\text { Can perform active participation in class } \\
\text { activities? }\end{array}$ & 20 & 16 & $(80 \%)$ & $4(20 \%)$ \\
\hline 7 & Independently perform the activities? & 20 & 19 & $(90 \%)$ & $1(5 \%)$ \\
\hline
\end{tabular}

Table 7 reveals under the psychomotor domain of students achievement on the basis of experiential learning that $100 \%$ students were able to perform certain actions by instructions and concentrated on topic/activities; $90 \%$ students independently performed the activities; 
85\% responded effectively to experience; $85 \%$ students felt any competent in task; $75 \%$ students observed and replicated in activities whereas, $25 \%$ students did not observe and replicate in activities and $20 \%$ did not perform active participation in class activities.

The psychomotor domain of the students' achievement ranged from $75 \%$ to $100 \%$. Students' achievement under the statement "observe and replicate in activities" was the lowest.

\section{Discussion}

The research was to examine consequences of experiential learning on the pupils' motivation and interest at the elementary Level in subject of the General Science. Objectives of study contained; (i) to investigate the consequence of the experimental learning on the pupil's motivation towards learning; (ii) to measure the result of experimental learning on pupil's interest towards the learning by using the experimental learning. A total of 40 students studying in elementary school were taken randomly as the model of study. A pretest and the posttest alike group designs was applied in learning. Teacher made tests were developed for collection of data. Observation sheets and questionnaire were developed to measure the motivation and interest of the students. Statistical techniques given as percentages, means, standard deviations, and T-test applied to examine collected information. Report was significant for students, teachers, curriculum developers and future researchers.

On basis of the findings of the posttest scores, t-value (3.781) found bigger than the table values (2.042) at 0.05 levels. So, the null hypothesis refused and the $t$-value presented there was found a important variance among the means score of the high achievers of the experimental group and the control group. Therefore, means score (21.82) of the experimental groups was greater than means score (17.00) of the control groups. It indicates that experiential learning of students' achievement is significantly better than traditional learning and results of report supported the conclusions of studies reported by the Bibian (2014) that experiential learning had been important consequence on the pupils' attainment. Results of the post-test score shows the t-value (2.157) found bigger than the table value (2.11) at 0.05 level.So, null hypothesis was rejected and t-value showed the significant variance among the means score of the low achievers of the experimental group and the control group. Therefore, means score (10.78) of the experimental groups found higher than the means score (8.00) of the control groups. It means that experiential learning of students' achievement is better than traditional learning and consequences of study supported findings of studies reported by the Mate and Ryan`s (2015) that experiential learning had been important outcome on the scholars' success.

On basis of the results and experiential learning, the cognitive domain of students' achievement showed that $100 \%$ students were attentive in the class and understanding the topic. Overall the percentage of cognitive domain ranged from $70 \%$ to 100 percent. In cognitive domain the learning ability to recall information was $70 \%$ the lowest in the range. This showed highest level of motivation in cognitive domain.

Under the affective domain of students achievement on the basis of experiential learning it showed that $100 \%$ students showed interest in the class and actively participated in the lesson; 90\% students felt enjoy helping other students, 75\% students showed responsibility 
for the functioning of her group; $65 \%$ students discussed with other students properly, $75 \%$ students participated as motivator while $35 \%$ students did not discuss with other students properly and $40 \%$ students participated as motivator. The affective domain of students' achievement ranged from $75 \%$ to $100 \%$.

The psychomotor domain of students' achievement, based on experiential learning, revealed that the bulk of pupils were capable to perform certain actions by instructions and concentrated on topic/activities; students independently performed the activities; responded effectively to experience; students felt competent in task; observed and replicated in activities. The accomplishment of the students in the psychomotor area ranged from $75 \%$ to $100 \%$. In comparison to other activities, students' achievement in the statement "observe and recreate in activities" was the lowest.

\section{Conclusions}

- Student's motivation and interest was improved as a result of experiential learning adopting as teaching method.

- On the basis of results and experiential learning, the cognitive domain of students' achievement showed that $100 \%$ students were attentive in the class and understanding the topic. Overall the percentage of cognitive domain ranged from $70 \%$ to $100 \%$. In cognitive domain the learning ability to recall information was $70 \%$ the lowest in the range. This showed highest level of motivation in cognitive domain.

- Under the affective domain of students achievement on the basis of experiential learning it showed that $100 \%$ students showed interest in the class and actively participated in the lesson; 90\% students felt enjoy helping other students, $75 \%$ students showed responsibility for the functioning of her group; $75 \%$ students discussed with other students properly, $80 \%$ students participated as motivator while $35 \%$ students did not discuss with other students properly and $80 \%$ students participated as motivator. The affective domain of students' achievement ranged from $75 \%$ to $100 \%$.

- $\quad$ On the basis of experiential learning, the psychomotor domain of students achievement showed that majority of the students were able to perform certain actions by instructions and concentrated on topic/activities; students independently performed the activities; responded effectively to experience; students felt competency in tasks; students observed and replicated in activities. The psychomotor domain of the students' achievement ranged from $75 \%$ to $100 \%$. Students' achievement under the statement "observe and replicate in activities" was the lowest as compared to other activities.

\section{Recommendations}

- Teachers should be stimulated to practice experimental learning method in the instructional concepts and emerging skills to deliver pupils with extra expressive learning and attain better consequences.

- School officials and departments administrators may advise the usage of experimental learning method to over-all science instructors.

- Tutors in the diverse subjects of the prospectus prepared actions in the subject expending experimental learning method. 


\section{Acknowledgements}

The writers would like to say thanks participants for their active roles.

\section{References}

1. Bibian, O. N. (2014). Effect of Kolb's 4-Stge Cycle of Experiential Learning on Student's Performance and Interest in Vegetable Crops Production in Senior Secondary School in Anambra State, Nigeria. University of Nigeria, Nsukka.Faculty of Education.

2. Bonnycastle, M. M., \& Bonnycastle, C. R. (2010). Photographs generate knowledge: Reflections on experiential learning in/outside the social work classroom. Journal of Teaching in Social Work, 104(4), 233-250. https://doi.org/10.1080/08841233.2015.1027031

3. Chana, C. K. (2012). Exploring an experiential learning project through Kolb's Learning Theory using a qualitative research method. European Journal of Engineering Education, 37(4), 405-415.

4. Chavan, M. (2011). Higher education students' attitudes towards experiential learning in international business. Journal of Teaching in International Business, 22(2), 126143.https://doi.org/10.1080/08975930.2011.615677

5. Chen, P. (2012). Empowering identity reconstruction of indigenous college students through transformative learning. Educational Review, 64(2), 161-180. https://doi.org/10.1080/00131911.2011.592574

6. Chmielewski-Raimondo, D. A., McKeown, W., Brooks, A. (2016). The field as our classroom: Applications in a business-related setting. Journal of Accounting Education, 34, 41-58. https://doi.org/10.1016/.jaccedu.2015.11.002

7. Coetzee, L. R. (2011). The relationship between students' academic self-concept motivation and academic achievement at the university of the Free State. Retrieved from http://uir.unisa.ac.za/handle/10500/4346

8. Earnest, D. R., Rosenbusch, K., Wallace-William, D., \& Keim, A.C. (2016). Study abroad in psychology: increasing cultural competencies through experiential learning. Teaching of Psychology, 43(1), 75-79. https://doi.org/10.1177/0098628315620889

9. Farooq, R. A. \& Tabassum, R. (2017).Understanding Research in Education. Pakistan: Lahore. Majeed Book Depot.

10. Greenfield, E. A., Davis, R. T., \& Fedor, J. P. (2012). The effect of international social work education: Study abroad versus on-campus courses. Journal of Social Work Education, 48(4), 739-761. https://doi.org/10.5175/ISWE.2012.201100147

11. Groot, D. M., Alexander, K., Culp, B., \& Keith, N. (2015). Experiential learning in kinesiology: A student perspective. Pedagogy in Health Promotion, 1(3), 123-133. https://doi.org/10.1177/2373379915594391

12. Henoch, I., Ung, E. J., Ozanne, A., Falk, H., Falk, K., Sarenmalm, E. K., Ohlen, J., \& Fridh, I. (2014). Nursing students' experiences of involvement in clinical research: an exploratory study. Nursing Experience in Practice, 14(2), 188-194.https://doi.org/10.1016/j.nepr.2013.07.009

13. Javed, S., Hussain, N., \& Karim, T. S. (2014). A shift from teacher centered to experiential teaching method: A Case Study. Pakistan Business Review, 16(1), 1-33.

14. Jeyaraj, J. S. (2019). Traditional learning vs. experiential learning. American College Journal of English Language and Literature (ACJELL), 9, 43-46.

15. Kamath, S. (2014). Experiential learning vs. traditional learning methodologies. Retrieved from https://www.knolskape.com/experiential-learning-vs-traditional-learning-methodologies

16. Kolb, A. Y., \& Kolb, D. A. (2005). Learning styles and learning spaces: Enhancing experiential learning in higher education. Academy of Management Learning \& Education, 4(2), 193-212. https://doi.org/10.5465/AMLE.2005.17268566 
17. Lai, E. R. (2011). Motivation: A literature review. International Journal of Management, 11(1), 324331.

18. Lewis, M. L., Rappe, P. T., Albury, J. D., \& Edler, L. D. (2017). Creative teaching and reflection in nontraditional settings: Regional, national, and international experiences. Social Development Issues, 39(1), 29-40.

19. Lin, Y., Lai, P., Chiu, Y.C., \& Chen, Y. (2016).Taiwanese university students' perspectives on experiential learning and psychosocial development. College Student Journal, 50(4), 603-613.

20. Mate, S., \& Ryan, M. (2015). Learning through work: How can a narrative approach to evaluation build students' capacity for resilience? Asia Pacific Journal of Cooperative Education, 16(3), 153161.

21. McGuire, M., Goldstein, C., Claywell, L., \& Patton, R. (2017). Analysis of student reflections of experiential learning in nursing health policy courses. Nurse Educator, 42(2), 95-99. https://doi.org/10.1097/NNE.0000000000000321

22. Philips, L., Bloom, T., Gainey, T., \& Chiocca, E. (2017). Influence of short-term study abroad experiences on community health baccalaureate students. Journal of Nursing Education, 56(9), 528-533. https://doi.org/10.3925/01484834- 20170817-03

23. Reade, C., Reckmeyer, W. J., Cabot, M., Jaehne, D., \& Novak, M. (2013). Educating global citizens for the 21st century: The SJSU Salzburg program. Journal of Corporate Citizenship, 49,100-116. https://doi.org/10.2307/jcorpciti.49.100

24. Roholt, R. V., \& Fisher, C. (2013). Expect the unexpected: International short-term study course pedagogies and practices. Journal of Social Work Education, 49(1), 48-65. https://doi.org/10.1080/10437797.2013.755416

25. Stoner, L., Perry, L., Wadsworth, D., Stoner, K.R., \& Tarrant, M.A. (2014). Global citizenship is key to securing global health: The role of higher education. Preventive Medicine, 64, 126-128. https://doi.org/10.1016/i.ypmed.2014.05.006.

26. Strange, H., \& Gibson, H.J. (2017). An investigation of experiential and transformative learning in study abroad programs. Frontiers: The Interdisciplinary Journal of Study Abroad, 29(1), 85-100. https://doi.org/10.36366/frontiers.v29i1.387

27. Tiessen, R., \& Epprecht, M. (2012). Introduction: Global citizenship education for learning/ volunteering abroad. Journal of Global Citizenship \& Equity Education, 2(1), 1-12. Tsunesaburo $\begin{array}{llll}\text { Makiguchi. (n.d.) Life's } & \text { Values. }\end{array}$ https://www.tmakiguchi.org/educator/educationalreformer/lifesvalues.html

28. Turabik, T., \& Baskan, G. A. (2015). The importance of motivation theories in terms Of education systems. Procedia - Social and Behavioral Sciences, 186, 1055-1063. http://doi.org/10.1016/j.sbspro.2015.04.006

29. Zhu Y \& Yang J 2012. Effects of farmers' motivation on their participation in publicly funding training programs in Sichuan province, China. Journal of Agricultural Science, 4(10):68-74. https://doi.org/10.5539/jas.v4n10p68 